\title{
Infrared Camera Measurements Reveal Diurnal Variation in the Effect of Mechanically Induced Internal Voids on Stem Temperatures of Small Trees Passively Heated by the Sun
}

\author{
Daniel C. Burcham, Eng-Choon Leong, Yok-King Fong, and Puay-Yok Tan
}

\begin{abstract}
The relationship between stem temperature measured by an infrared (IR) camera and a tree's internal condition was proposed as a basis for diagnosing potentially hazardous defects in the landscape. Before practical application, this diagnostic technique needs clarification to guide expectations of its resolution and precision. In this study, cylindrical voids of varying size were created in $5 \mathrm{~cm}$ diameter stems of Dracaena fragrans and Syzygium grande by mechanically removing tissue from specimens in an outdoor nursery, and the surface temperature of these plants was measured twice daily at $0830 \mathrm{~h}$ and $1830 \mathrm{~h}$ using an IR camera. The collected IR images were analyzed using a concurrent mixed methods approach with qualitative image evaluation and quantitative temperature analysis where the temperature distributions of stems containing internal voids were compared to those without defects. For both species, there was no difference in stem temperatures, as observed in IR images, among any experimental plants at 0830h, but an anomalous temperature reduction was exclusively apparent at $1830 \mathrm{~h}$ near the $3.8 \mathrm{~cm}$ void, occupying $76 \%$ stem cross-sectional area. There was also a larger decrease in the linear temperature trend $\left(0.34^{\circ} \mathrm{C}-0.51^{\circ} \mathrm{C}\right)$ near this void margin compared with other treatments, although this was more pronounced in the monocot species than eudicot. The remaining treatments did not exhibit stem temperatures visibly different from the control. Under experimental conditions, the technique identified relatively large internal defects, but the reduced heat capacity of stems containing such defects is only apparent in the evening after being passively heated by the sun.

Key Words. Diagnostic Device; Dracaena fragrans; Infrared Camera; Internal Defect; Singapore; Syzygium grande, Temperature; Thermal.
\end{abstract}

The application of diagnostic devices during tree risk assessments is common among practicing arborists who need detailed information about a tree's internal condition. The devices measure material property changes in the stem associated with degraded wood to assess the presence, and in some cases, severity of internal defects. The devices often employ physical measurement techniques to evaluate internal defects, including penetration resistance, acoustic stress wave transmission, and electrical resistivity (Nicolotti and Miglietta 1998; Larsson et al. 2004; Deflorio et al. 2008; Wang and Allison 2008). Ultimately, arborists consider the output of these devices during formal tree risk assessments when judging the overall risk presented by a tree in its surrounding landscape. These assessments are informed by three separate considerations, including the probability that a tree will fail within a given time period, the likelihood this failure will result in damage or harm, and the severity of these outcomes, often measured in financial terms (Matheny and Clark 1994; Ellison 2005). Of these considerations, the first is often the most difficult to resolve accurately. A subjective assessment prescribing the likelihood that a tree will fail is often imprecise and ambiguous, and accurate formulas describing strength loss caused by internal decay are currently not available (Kane and Ryan 2003; Kane and Ryan 2004; Norris 2008). The availability of accurate and easy-to-use tree diagnostic devices, in particular, is essential to support this decision-making process.
Over the past fifty years, forestry and lumber professionals have developed many of the techniques for identifying and assessing internal defects (Beall and Wilcox 1987; Brashaw et al. 2009), and the arboriculture profession has adopted several of these for practical use (Matheny and Clark 2009; Johnstone et al. 2010; Leong et al. 2012). However, the great size and longevity of many tree species and complex plant-microbe interactions, coupled with limited scientific resources, has constrained the extent of systematic testing imposed on these devices. Arboriculture research addressing this topic has frequently relied on a relatively small sample of trees and inconsistent methodological approaches to determine a device's measurement resolution (i.e., detection capability) and precision. As a result, the conclusions drawn from these studies may inhibit their straightforward application to an urban forest (Matheny and Clark 2009). Additional research focusing on diverse tree species, pathogens, and habitats is needed to help clarify the capabilities and constraints of the devices.

Recently, the capability of an infrared (IR) camera to be employed as a tree diagnostic device has been the focus of several studies. Its proposal as a rapid, general, and accurate tree diagnostic device suggests its utility in managing the time requirements and providing detailed information for tree risk assessments (Catena and Catena 2008). The proposed technique evaluates stem surface temperature measurements captured by an IR camera for thermal property changes associated with degraded wood. The presence of structural defects, such as 
wood decay lesions, cavitations, or cracks, may initiate changes to the wood's thermal properties (i.e., thermal conductivity, heat capacity, thermal diffusivity) that produce visibly different surface temperature distributions under certain heating and atmospheric conditions. These thermal properties are mostly governed by wood density, moisture content, extractives, grain direction, structural discontinuities, and cellular microfibril angle; and some defects may, in certain cases, significantly alter these characteristics (Forest Products Laboratory 2010). The association of decayed wood with tree failures has resulted in this defect being of particular concern for practicing arborists, and the close association of relatively cool stem surface temperatures with internal decay was reported as the basis of this diagnostic technique (Catena et al. 1990; Schwarze et al. 2000). However, initial reports largely employed qualitative analytical methods to interpret the images for surface temperature anomalies indicating the presence of internal defects, and significant unrealized development potential remains in designing the analytical techniques used to interpret the images (Catena and Catena 2008).

In recent studies, the relationship between a stem's internal condition and its surface temperature has been systematically evaluated (Bellett-Travers and Morris 2010; Burcham et al. 2011; Burcham et al. 2012). In particular, one study demonstrated a relationship between these two features exclusively in stems containing internal defects exceeding $76 \%$ stem crosssectional area (Burcham et al. 2012). These results suggest a relatively low workable resolution for the device that omits defects below this minimum threshold value, and these findings are critical in defining the conditions under which the IR camera technique may practically be deployed for use in the field. In a separate study, the internal condition of landscape Casuarina equisetifolia specimens did not explain the variability $\left(r^{2}=0.001-0.022\right)$ in surface temperature measurements captured with an IR camera when internal defects occupied up to $21.8 \%$ stem cross-sectional area (Burcham et al. 2012). These results are indirectly corroborative by failing to detect defects not exceeding the minimum threshold value previously determined. Still, the major conclusions about the technique's performance were derived primarily from experiments conducted with Dracaena fragrans, a monocot, under controlled environmental conditions, and it is critical that the veracity of these results be confirmed with eudicot species in an uncontrolled, outdoor environment. The anatomy of monocots differs substantially from that of eudicots, the class of flowering plants containing most hardwood tree species planted in cities. In this case, the important difference is the distribution of tissue systems within the stems, with eudicots having a continuous cylinder of vascular tissue enclosing some ground tissue (i.e., pith) and surrounded by more (i.e., cortex), and monocots having vascular bundles scattered throughout the ground tissue (Evert 2006). Therefore, two experiments were designed using a monocot and eudicot species, Dracaena fragrans (L.) Ker Gawl. (Agavaceae) and Syzygium grande (Wight) Wight ex Walp. (Myrtaceae), respectively, chosen for their frequent use in Singapore. The objectives of the study were to evaluate, under controlled conditions in a nursery: 1) the effect of mechanically induced internal voids on the stem surface temperature distributions of monocot and eudicot species using an infrared camera, and 2) diurnal variation in this relationship affected by ambient atmospheric conditions in the equatorial tropics.

\section{MATERIALS AND METHODS}

In this study, two similar experiments were conducted using different plant species. In the first, seven $D$. fragrans specimens were selected from a single nursery source using three predefined selection criteria, including a $5 \mathrm{~cm}$ stem diameter (measured at $10 \mathrm{~cm}$ height), an absence of stem defects, such as mechanical damage, cracks, or detached bark, and a single straight apical leader. The relative physiological maturity of the plants was held constant by selecting individuals from the same nursery crop rotation. In the second, eight $S$. grande were selected from a single nursery source using the same criteria.

Subsequently, the commercial growing media was removed from the root systems of individual plants to transfer them into a larger container size. During this process, longitudinal voids were introduced mechanically into selected stems using wood auger drill bits. The voids were introduced axially from the bottom of the stem, made accessible by the bare root system, and centered along the stem midpoint (pith in $S$. grande). Root damage was mostly avoided with $D$. fragrans as the adventitious roots generated during vegetative propagation were arranged at the stem periphery, but some damage was inevitably caused to the wood structural roots in secondary growth that obscured the bottom of the $S$. grande stem (Figure 1). The voids occupied between $25 \%-76 \%$ of stem cross-sectional area and extended $5-35 \mathrm{~cm}$ above the root flare. In each experiment, the voids were introduced into all specimens except for two (i.e., Plants 1 and 2), which were preserved as control treatments (Figure 2; Table 1).

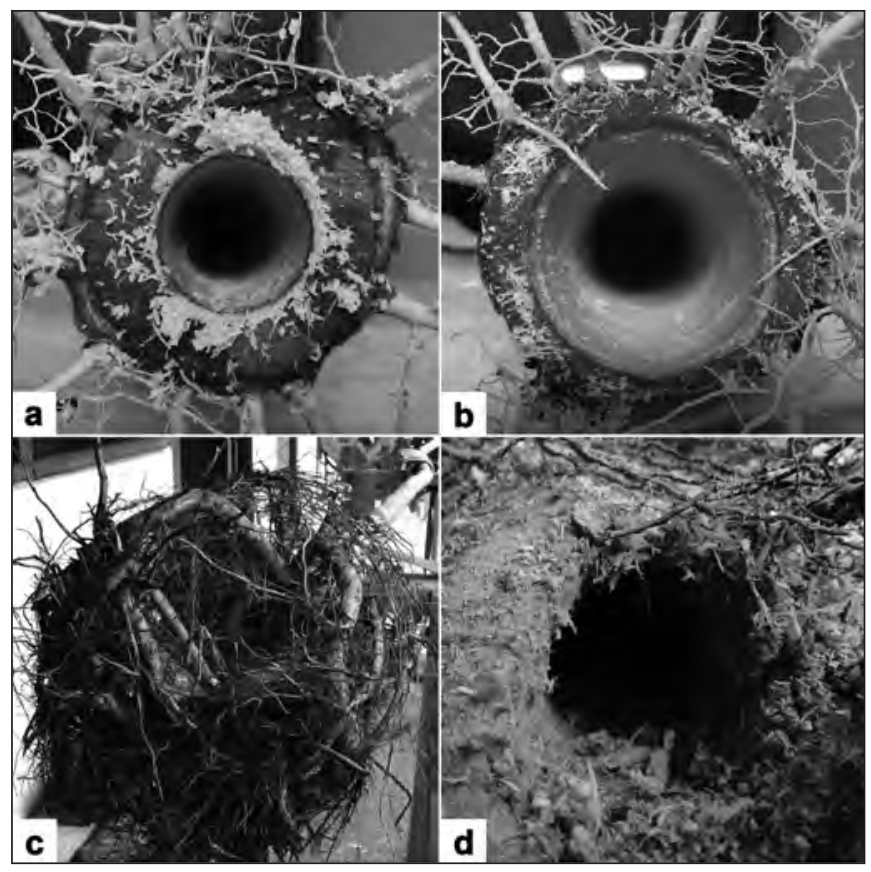

Figure 1. Commercial growing media was removed from the root systems of Dracaena fragrans (a, b) and Syzygium grande (c, d) to access the bottom of the stem, and longitudinal voids were subsequently introduced using wood auger drill bits. Inadvertent root damage was avoided insofar as possible during the void introduction process. 


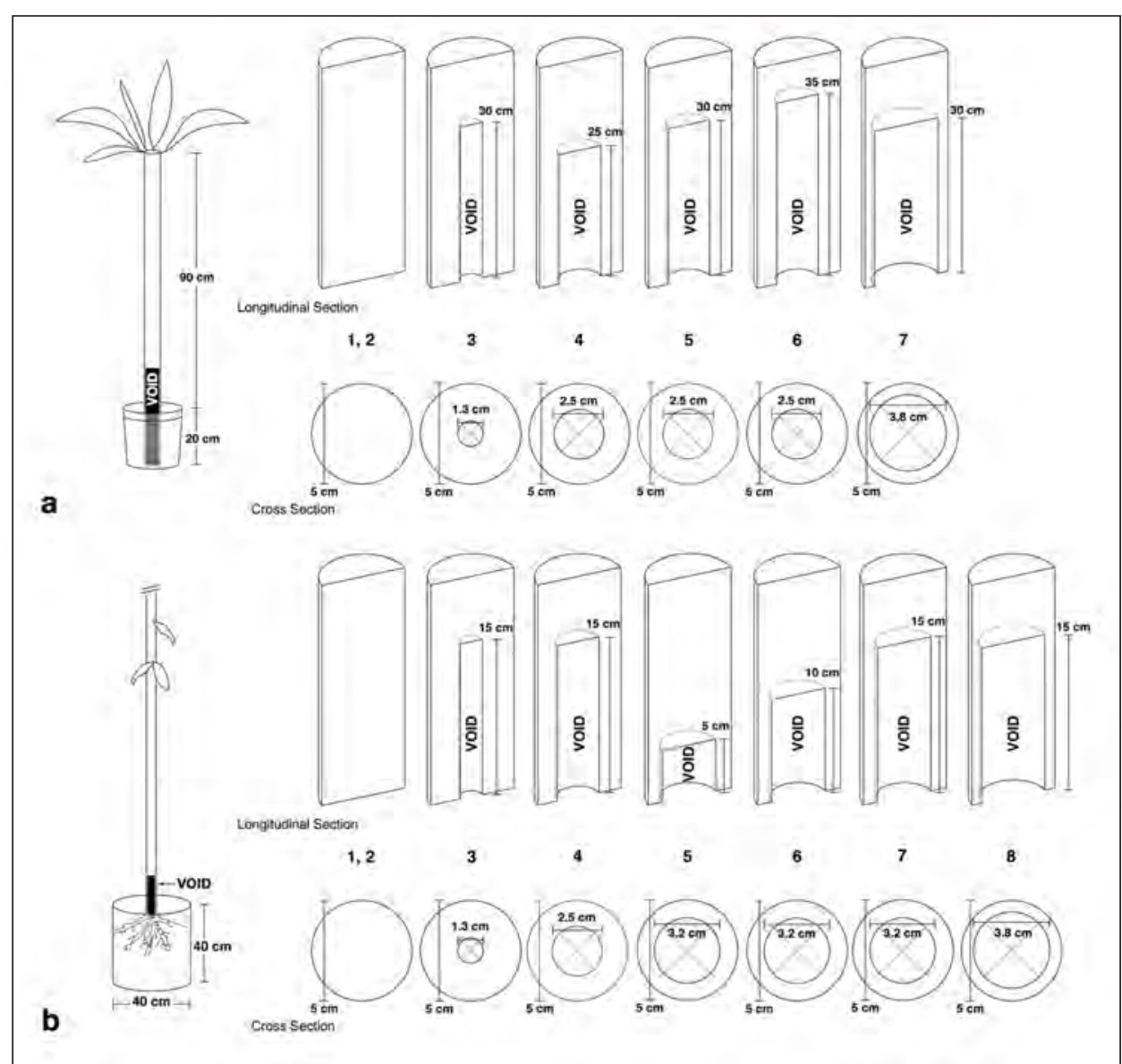

Figure 2. The mechanically induced voids ranged in size from 1.3 to $3.8 \mathrm{~cm}$ diameter in both Dracaena fragrans (a) and Syzygium grande (b). The voids were oriented axially along the stem center (pith in S. grande) and extended between 5 and $35 \mathrm{~cm}$ above the root flare.

The $D$. fragrans were subsequently placed in cylindrical plastic pots $(21 \mathrm{~cm} \times 21 \mathrm{~cm})$ filled with a soilless, coconut husk-based potting mix, and the $S$. grande were placed in cylindrical plastic bags $(40 \mathrm{~cm} \times 40 \mathrm{~cm})$ filled with a soil mixture consisting of three parts clay loam, two parts compost, and one part washed sand. The plants were randomly arranged in two species-specific pot-to-pot linear rows in an outdoor nursery under natural photoperiods. The plants were protected from precipitation by a permanent rain shade located immediately above the row of plants, and the containers were irrigated to container flow-through every 72 hours. The plants were maintained under these conditions for an establishment period lasting four weeks. In both experiments, Plant 1, the non-irrigated control, was watered during this period and irrigation was thereafter permanently withheld.

After the establishment period, the stem surface temperature was measured twice daily at $0830 \mathrm{~h}$ and 1830h using a Thermoteknix VisIR 640 IR camera (Cambridge, UK), with $0.05^{\circ} \mathrm{C}$ thermal sensitivity, calibrated using ambient temperature and target emissivity values. Stem surface temperature measurements were captured from a consistent, fixed position and replicated over four days. The IR camera was positioned at a distance of 3.45 $\mathrm{m}$ and a height of $1 \mathrm{~m}$ when measuring $D$. fragrans, and these values were held at $1.2 \mathrm{~m}$ and $0.7 \mathrm{~m}$, respectively, when measuring $S$. grande. At these distances, the camera captured all $D$. fragrans simultaneously and individual $S$. grande stems within its field of view. The stems of the latter were measured individually to maintain acceptable measurement accuracy, which may decrease at greater ranges from the target object with the IR camera. Throughout the experiment, local atmospheric conditions, including temperature $\left({ }^{\circ} \mathrm{C}\right)$ and relative humidity $(\%)$ were recorded hourly using a Hobo ${ }^{\circledR}$ Pro Series H08-032-08 data logger (Onset Corporation, Cape Cod, Massachusetts,

Table 1. Physical characteristics of mechanically induced voids in Dracaena fragrans and Syzygium grande stems.

\begin{tabular}{|c|c|c|c|c|c|}
\hline \multirow[b]{2}{*}{ Experiment } & \multirow[b]{2}{*}{ Treatment } & \multicolumn{4}{|c|}{ Characteristics of void } \\
\hline & & Diameter $(\mathrm{cm})$ & $\begin{array}{l}\text { Height above } \\
\text { soil }(\mathrm{cm})\end{array}$ & $\begin{array}{l}\text { Relative cross- } \\
\text { sectional area }(\%)\end{array}$ & Volume $\left(\mathrm{cm}^{3}\right)$ \\
\hline Set 1 & 1 & 0.0 & 0.0 & 0.0 & 0.0 \\
\hline \multirow[t]{6}{*}{ D. fragrans } & 2 & 0.0 & 0.0 & 0.0 & 0.0 \\
\hline & 3 & 1.2 & 30.0 & 25 & 33.9 \\
\hline & 4 & 2.5 & 25.0 & 50 & 122.7 \\
\hline & 5 & 2.5 & 30.0 & 50 & 147.3 \\
\hline & 6 & 2.5 & 35.0 & 50 & 171.8 \\
\hline & 7 & 3.8 & 30.0 & 76 & 340.2 \\
\hline Set 2 & 1 & 0.0 & 0.0 & 0.0 & 0.0 \\
\hline \multirow[t]{6}{*}{ S. grande } & 2 & 0.0 & 0.0 & 0.0 & 0.0 \\
\hline & 3 & 1.2 & 15.0 & 25 & 17.0 \\
\hline & 4 & 2.5 & 15.0 & 50 & 73.6 \\
\hline & 5 & 3.2 & 5.0 & 65 & 40.2 \\
\hline & 6 & 3.2 & 10.0 & 65 & 80.4 \\
\hline & 7 & 3.2 & 15.0 & 65 & 120.6 \\
\hline
\end{tabular}


U.S.). Total solar radiation $\left(\mathrm{kWh} / \mathrm{m}^{2} /\right.$ day $)$ measurements for the surrounding environs were obtained from the Meteorological Services Division, National Environment Agency, Singapore.

The collected data were analyzed using a concurrent, mixed methods procedure in an attempt to confirm and corroborate findings gained from both qualitative and quantitative methods (Greene et al. 1989). The two data types were analyzed concurrently with equal priority given to each category, and the results were integrated during the interpretation and discussion phase.

\section{Qualitative Analytical Methods}

Individual IR images were processed using the TherMonitor ${ }^{\circledR}$ Reporter System (Thermoteknix 2001) after collection. The temperature span rendered in each image was held constant among images collected at the same time of day, and the captured images were compared visually for obvious differences in stem temperature distributions. The consistent appearance of warm or cool temperature anomalies across space and time was recorded, and these areas were compared with the known internal and external features of the experimental plants.

\section{Quantitative Analytical Methods}

Temperature readings were extracted from the stem surfaces captured by the IR image using two separate techniques. First, temperature data were extracted from longitudinal rectangular transects $(10 \mathrm{~cm} \times 5 \mathrm{~cm})$ positioned horizontally central across the stem immediately above the top of the container in order to capture stem surface temperatures overlying the internal voids (Figure 3) similar to Burcham et al. (2011). Statistical representation of these surface temperatures

was derived using measures of central tendency, the mean: $\bar{t}=\frac{\sum t_{i}}{n}$ and mean surface-air temperature differential: $\bar{t}=\frac{\sum t_{i}-t_{a m b}}{n}$ ; variability, the standard deviation: $s=\sqrt{\sum\left(t_{i}-\bar{t}\right)^{2} / n-1}$; and distribution symmetry, Pearson's skewness coefficient: $s k=\frac{\bar{t} \text {-mode }}{s}$.

In these formulas, $t_{i}$ represents the temperature measured at point $\mathrm{i}, \mathrm{t}_{\mathrm{amb}}$ represents the ambient temperature at the time of data collection, $\bar{t}$ represents the mean temperature, and $\mathrm{n}$ represents the total number of points within the transect.

Second, temperature data were extracted from three longitudinal lines positioned equidistant across the measured stem surface (Figure 3). The measurements, obtained at regular intervals of approximately $0.4 \mathrm{~cm}$ for $D$. fragrans and $0.2 \mathrm{~cm}$ for $S$. grande were averaged to combine values into a single column representing the vertical temperature change along a $90 \mathrm{~cm}$ gradient. These temperature data extracted from each treatment were plotted against the corresponding stem height for comparison with each treatment's values offset consistently by $+1^{\circ} \mathrm{C}$ greater than the preceding treatment's to avoid overlapping lines in the coordinate plane (Figure 5; Figure 6). Subsequently, the linear temperature plots were examined visually for irregularities in trending compared with the irrigated control (Plant 2), and individual temperature measurements were compared with the mean surface temperature at purposefully selected reference points. These points were selected based on the position of temperature anomalies observed in the infrared images proximal to the introduced voids. Localized

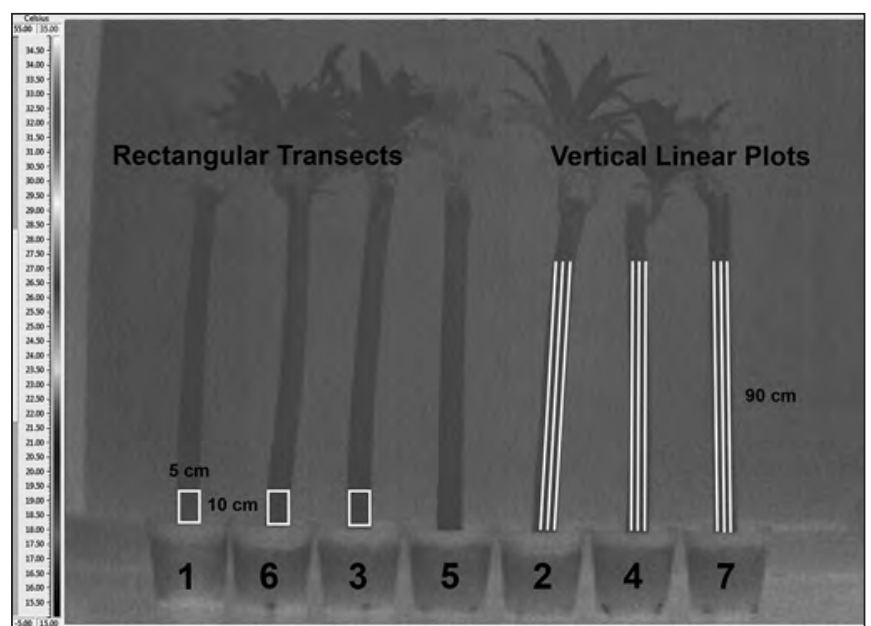

Figure 3. Temperature data were extracted from longitudinal rectangular transects positioned horizontally and central across the stem surface overlying the internal voids (left) and three evenly distributed lines longitudinally oriented along the stem surface (right).

deviation from the mean surface temperature $\left(\bar{t}-t_{i}\right)$ at this reference point was determined for each extracted temperature line.

\section{Statistical Analysis}

The stem surface temperature (means, standard deviation, skewness) and localized deviation from linear trend among the treatments were compared to the irrigated control (Plant 2) using paired t-tests $(\alpha=0.05)$. Assumptions of normality and homoscedasticity were checked. Statistical tests were conducted in SPSS Statistics 19.0 for Windows (IBM Corp. 2010).

\section{RESULTS}

The two experiments with $D$. fragrans and $S$. grande were conducted separately between June 15-18 and August 10-13, 2011, respectively. During these periods, diurnal variation in atmospheric conditions was typical for Singapore. Daily temperatures had a range of $26^{\circ} \mathrm{C}-34^{\circ} \mathrm{C}$ and the relative humidity had a range of $65 \%-86 \%$ (Figure 4 ). On average, the study site received $4.7 \mathrm{kWh} / \mathrm{m}^{2} /$ day of solar radiation during the same periods.

Visual evaluation of infrared images captured at $0830 \mathrm{~h}$ during the two experiments (Figure 5) did not reveal obvious variation in stem temperature among the plants. At this time of day, the temperature distributions observed on all treatments were spatially homogenous along the entire stem surface captured by the image. In particular, the stem temperatures above the various void treatments did not appear different from the irrigated control (Plant 2).

In contrast, infrared images captured at $1830 \mathrm{~h}$ during both experiments (Figure 6) showed distinct surface temperature anomalies on two treatments. First, a localized area of relatively cool surface temperatures was visible on the plant containing the $3.8 \mathrm{~cm}$ void. These low temperatures were strongly associated with both the position and extent of the internal void introduced in this plant, and the temperature distributions for the others containing voids did not appear visibly different from the irrigated control. Second, the surface temperature of the non-irrigated control (Plant 1) appeared distinctively cooler and broadly homogenous along the entire stem surface captured by 


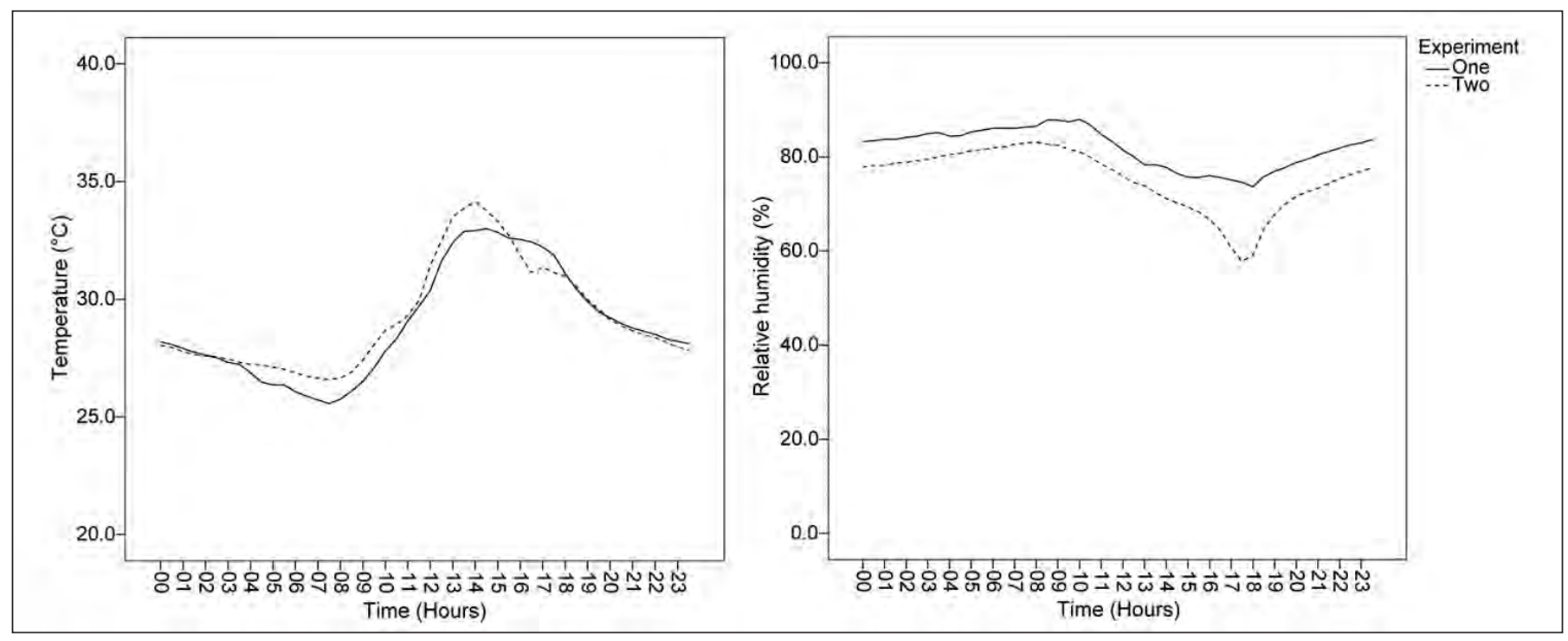

Figure 4. Average diurnal variation in temperature $\left({ }^{\circ} \mathrm{C}\right)$ and relative humidity $(\%)$ during the two experimental periods, lasting four days each, was typical for equatorial climatic conditions in Singapore. Experiment one was conducted between June 15-18 and experiment two between August 10-13, 2011. Note: error bars ( \pm SD) illustrate the observed variability in environmental parameters at regular intervals.

the image. Whereas a visible gradient of progressively cooler temperatures was visible at the base of the stem among all remaining treatments, this feature was uniquely absent from the non-irrigated control. With the exception of these two observations, the surface temperature distributions appeared visibly similar between the other treatments and the irrigated control.

Temperature data extracted from the rectangular transects displayed inconsistent relationships between the void treatments and each of the four evaluated statistics, including the mean temperature, mean surface-air temperature differential, standard deviation, and skewness. However, some obvious and consistent patterns were apparent when the measurements, representing separate treatments, were sorted from least to greatest. In both experiments, the non-irrigated control and the plant with the 3.8 $\mathrm{cm}$ void registered the lowest mean temperature within the transect among all plants measured in the evening. For D. fragrans, the average air-surface temperature differential for Plants 1 and 7 was $-1.64^{\circ} \mathrm{C}(\mathrm{SD} 0.29)$ and $-1.62^{\circ} \mathrm{C}$ (SD 0.41), respectively. For S. grande, these values for Plants 1 and 8 were $-0.92^{\circ} \mathrm{C}$ (SD 0.42) and $-0.81^{\circ} \mathrm{C}(\mathrm{SD} 0.78)$. The values for these two treatments were reasonably close to one another at $1830 \mathrm{~h}$, their values being separated by $0.02^{\circ} \mathrm{C}$ in the first experiment and $0.11^{\circ} \mathrm{C}$ in the second, while all remaining treatments registered warmer temperatures. Overall, paired t-tests of mean temperatures did not reveal significant differences between the surface temperature for the stems containing the void treatments and irrigated control (Appendix).

In addition, the temperature distribution skewness within the rectangular transect on the plant with the $3.8 \mathrm{~cm}$ void in both experiments notably diverged from the other treatments at 1830h (Appendix). At this time of day, the surface temperature distributions above this void were skewed to the right (i.e., positive values) while all remaining treatments were skewed to the left (i.e., negative values). Paired t-tests conducted with these data, however, revealed that only the non-irrigated control for both $D$. fragrans and $S$. grande was skewed significantly greater than the irrigated control at $1830 \mathrm{~h}$, and $S$. grande Plants 3 , 6 , and 7 were skewed significantly greater than the irrigated control at the same time (Appendix). In contrast, the standard deviation of temperature distributions within the rectangular transects did not rank consistently when sorted from least to

Table 2. Localized stem temperature deviation from the mean surface temperature in linear temperature plots.

\begin{tabular}{|c|c|c|c|c|c|c|c|c|}
\hline \multirow{4}{*}{ Treatment } & \multicolumn{4}{|c|}{ Set 1: Dracaena fragrans ${ }^{z}$} & \multicolumn{4}{|c|}{ Set 2: Syzygium grande } \\
\hline & \multicolumn{2}{|l|}{$\begin{array}{l}\text { Time } \\
0830 \mathrm{~h}\end{array}$} & \multicolumn{2}{|l|}{$1830 \mathrm{~h}$} & $\begin{array}{l}\text { Time } \\
0830 \mathrm{~h}\end{array}$ & Time & $1830 \mathrm{~h}$ & \\
\hline & \multicolumn{4}{|c|}{ Deviation from linear trend $\left({ }^{\circ} \mathrm{C}\right)$} & \multicolumn{4}{|c|}{ Deviation from linear trend $\left({ }^{\circ} \mathrm{C}\right)$} \\
\hline & Mean \pm SD & $P$-value & Mean \pm SD & $P$-value & Mean \pm SD & $P$-value & Mean \pm SD & $P$-value \\
\hline 1 & $0.11 \pm 0.07$ & 0.361 & $0.17 \pm 0.07$ & 0.588 & $0.14 \pm 0.09$ & 0.389 & $0.03 \pm 0.11$ & 0.851 \\
\hline 2 & $0.06 \pm 0.09$ & - & $0.21 \pm 0.04$ & - & $0.09 \pm 0.08$ & - & $0.04 \pm 0.06$ & - \\
\hline 3 & $0.05 \pm 0.07$ & 0.908 & $0.15 \pm 0.02$ & 0.751 & $0.10 \pm 0.09$ & 0.878 & $-0.01 \pm 0.01$ & 0.551 \\
\hline 4 & $0.04 \pm 0.06$ & 0.728 & $0.28 \pm 0.04$ & 0.162 & $0.12 \pm 0.08$ & 0.575 & $0.08 \pm 0.13$ & 0.736 \\
\hline 5 & $0.05 \pm 0.10$ & 0.908 & $0.19 \pm 0.07$ & 0.821 & $0.08 \pm 0.09$ & 0.918 & $-0.04 \pm 0.17$ & 0.355 \\
\hline 6 & $0.04 \pm 0.01$ & 0.728 & $0.27 \pm 0.15$ & 0.188 & $0.14 \pm 0.02$ & 0.446 & $0.05 \pm 0.03$ & 1.000 \\
\hline 7 & $0.00 \pm 0.07$ & 0.306 & $0.51 \pm 0.14$ & $0.001^{y}$ & $0.10 \pm 0.08$ & 0.878 & $0.14 \pm 0.04$ & 0.337 \\
\hline 8 & - & - & - & - & $0.12 \pm 0.09$ & 0.646 & $0.34 \pm 0.16$ & $0.004^{y}$ \\
\hline
\end{tabular}

${ }^{2}$ Number of repeated measures $(\mathrm{n}=12)$.

${ }^{y}$ Represents a significant difference $(P<0.05)$ from Treatment 2 , the irrigated control. 


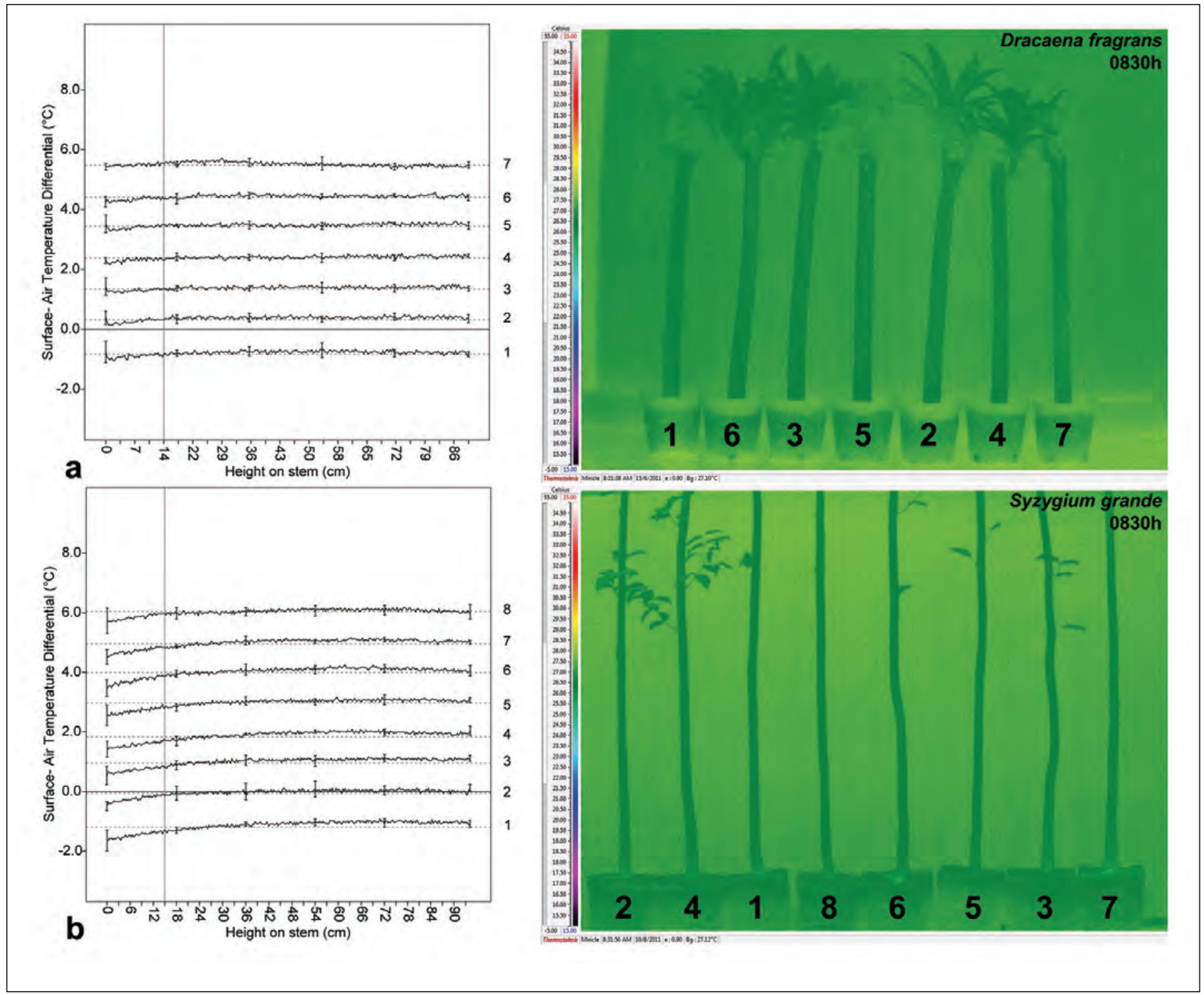

Figure 5. IR images taken in the morning revealed homogenous stem temperature distributions among all plants in both experiments; this was corroborated by the relatively uniform linear temperature trends for each treatment plotted in the coordinate plane. In the line graph, each treatment's values were offset consistently by $+1^{\circ} \mathrm{C}$ greater than the preceding treatment's to avoid overlapping lines in the coordinate plane. Note: The dashed horizontal reference lines show the modified treatment mean surface-air temperature differential, vertical reference line denotes the purposefully selected reference point, solid zero line represents the point at which unmodified treatment surface temperatures and ambient temperatures are identical, and the error bars $( \pm S D)$ illustrate the observed variability in surface temperature at regular intervals.

greatest, and there was no similarity in their measure between the two species. Paired t-tests conducted with these data revealed that the standard deviation on D. fragrans Plants 5, 6, and 7 at $1830 \mathrm{~h}$ was significantly lower than the irrigated control, and the standard deviation measured on $S$. grande Plant 8 at 1830h was significantly higher than the irrigated control (Appendix).

The linear temperature trends extracted from both $D$. fragrans and $S$. grande exhibited distinct uniformity among the plants measured at $0830 \mathrm{~h}$. There were no general or local changes in temperature along the measured stem surfaces, and the temperature trends for all the treatments were substantially similar to one another (Figure 5). At this time of day, none of the linear temperature deviation measurements at the selected reference points were significantly different from the irrigated control (Table 2). However, the linear temperature trends displayed noticeable differences among a few treatments when compared to the irrigated control at $1830 \mathrm{~h}$. The plants containing the $3.8 \mathrm{~cm}$ void exhibited an obvious temperature reduction, exceeding temperature trending and variability at similar points on other treatments, near the stem position overlying the internal void (Figure 6). In addition, the localized deviation from the average linear temperature at this position was 
significantly greater than that measured on the irrigated control (Table 2). In contrast, none of the remaining treatments exhibited linear temperature trends with anomalies of a similar magnitude, and the linear temperature deviation measurements for the remaining treatments were not significantly different from the irrigated control. In addition, the linear temperature trend for the non-irrigated control exhibited obvious uniformity compared with the irrigated control. Its linear trend most closely approximated a flat line in the evening, while the irrigated control and other void treatments exhibited a gradient of progressively cooler temperatures at the base of the stem.

\section{DISCUSSION}

In both experiments, stem temperature anomalies were exclusively observed on stems containing $3.8 \mathrm{~cm}$ internal voids, and this anomaly was only apparent at $1830 \mathrm{~h}$ in the evening. In the IR images taken at this time, obvious areas of relatively cool temperatures were consistently observed on stems containing the largest

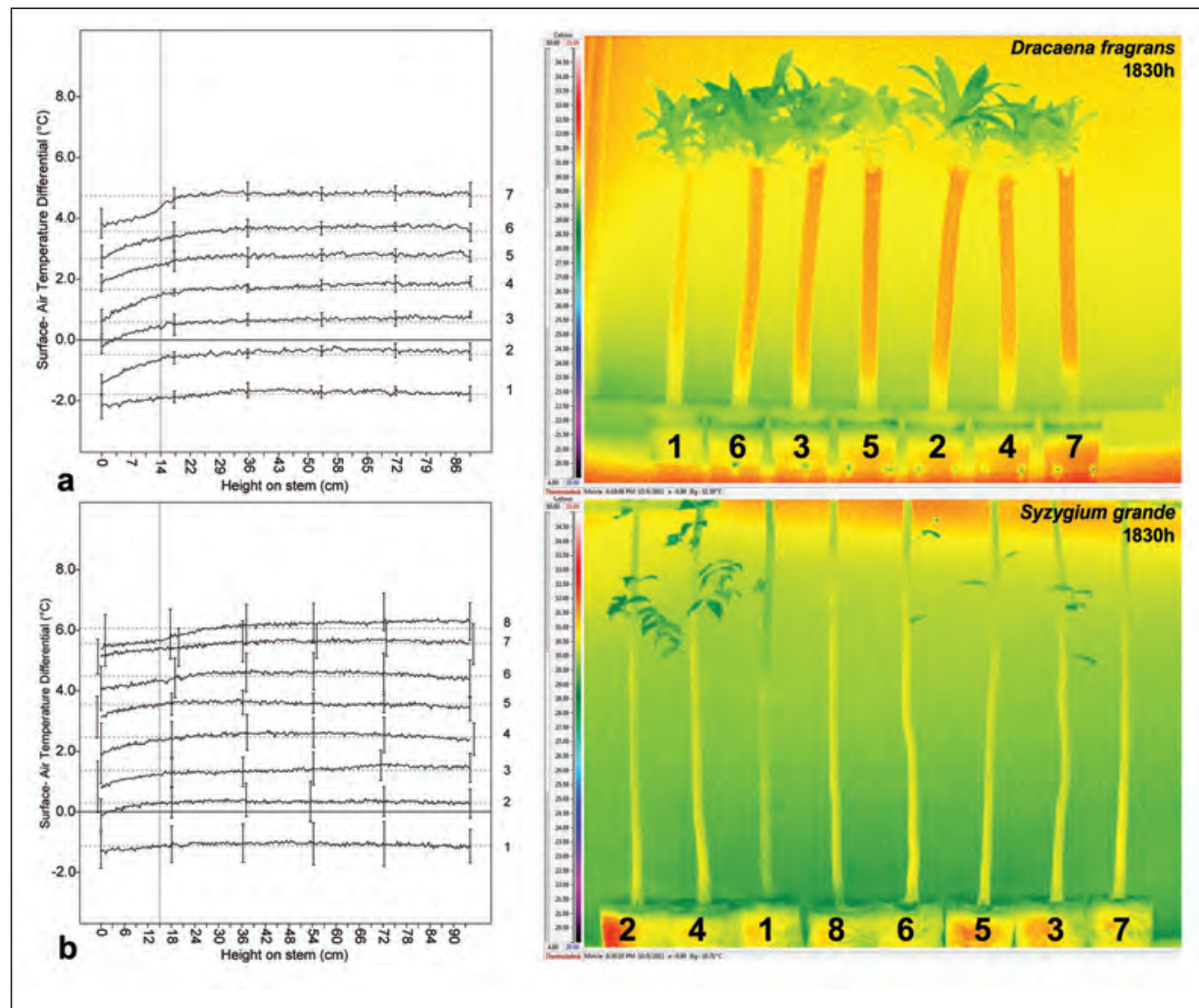

Figure 6. IR images taken in the evening revealed abnormal temperature reductions near the 3.8 cm internal void position in both experiments. Basal temperature gradients of progressively cooler temperatures were observed on all plants except one, the non-irrigated control, which presented a comparably cool, vertically homogenous temperature distribution. These observations were supported by a sharp deviation in the linear temperature trend near the $3.8 \mathrm{~cm}$ voids and the relatively flat trend line for the non-irrigated control, respectively. In the line graph, each treatment's values were offset consistently by $+1^{\circ} \mathrm{C}$ greater than the preceding treatment's to avoid overlapping lines in the coordinate plane. Note: The dashed horizontal reference lines show the modified treatment mean surface- air temperature differential, vertical reference line denotes the purposefully selected reference point, solid zero line represents the point at which unmodified treatment surface temperatures and ambient temperatures are identical, and the error bars ( \pm SD) illustrate the observed variability in surface temperature at regular intervals. voids, while the stem temperature distributions for the remaining plants were not obviously different from the irrigated control. In addition, these temperature anomalies were visibly associated with the internal void position as well as its general extent. Under ental conditions, these observations suggest that the infrared camera can be used to identify the existence, position, and broad extent of internal defects in the absence of externa stems contain relatively large areas of degraded tissue exceeding stem cross-sectional area. It is important to note, however, mature trees due to the important changes in size, shape, and soreover, these results 列 morning, there was no useful basis for differentiating between any of the treatments, but the temperature distribution exhibited by the stem with the largest void was clearly distinct in the evening.

In both experiments, the statistics derived from longitudinal rectangular transects did not fully corroborate the image evaluation process. Within each experiment, mean temperatures exhibited by the non-irrigated control and the plant containing the $3.8 \mathrm{~cm}$ void at $1830 \mathrm{~h}$ were relatively cool compared with all other treatments. However, none of the mean values in this experiment were significantly different from the irrigated control. In addition, mean temperature values representing the same treatment applied to different species were inconsistent. Notably, the average temperatures exhibited by the two plant species' irrigated controls were not the same at either time of day. The average surface-air temperature differential in the morning and evening for $D$. fragrans Plant 2 registered $-0.23^{\circ} \mathrm{C}$ and $-1.58^{\circ} \mathrm{C}$, respectively, while the same measures for S. grande Plant 2 were $-0.78^{\circ} \mathrm{C}$ and $-0.32^{\circ} \mathrm{C}$ (Appendix). Comparable interspecific variability in statistics representing surface temperatures within rectangular transects was observed between the stems containing the largest void in both experiments. While the $D$. fragrans stem containing the $3.8 \mathrm{~cm}$ void was, on average, $0.13^{\circ} \mathrm{C}$ and $1.62^{\circ} \mathrm{C}$ below ambient temperatures in the morning and evening, respectively, the same treatment applied to $S$. grande registered $0.58^{\circ} \mathrm{C}$ and $0.81^{\circ} \mathrm{C}$ below ambient temperatures at the same times of 
day (Appendix). It is possible that the planting depths used for each species may have contributed to the temperature differences between $D$. fragrans and $S$. grande stems containing the $3.8 \mathrm{~cm}$ void (Figure 2). The greater amount of soil surrounding the deeply planted $D$. fragrans stem may have acted as a buffer against temperature increases at the stem surface by cooling the air within the void, resulting in a relatively cool stem surface temperature above the $3.8 \mathrm{~cm}$ void for this species. Although the extension of the largest $D$. fragrans void into the soil facilitated its detection using the IR camera in this experiment, this unintentional artifact of experimental design is not likely to be encountered in the landscape.

In contrast to the mean temperatures, the standard deviation and skewness of the surface temperature distributions within the rectangular transects were, in some cases, significantly different from that exhibited by the irrigated controls (Plant 2). However, there was an inconsistent relationship between the absolute value and sorted position of these statistics among the experimental treatments. For example, the standard deviation of surface temperature distributions within the transect measured on D. fragrans Plants 5, 6, and 7 was significantly lower than the irrigated control (Plant 2), while the standard deviation measured on $S$. grande Plant 8 was significantly higher than the irrigated control. These statistics failed to draw any meaningful connections between the treatments and values obtained, and irregular changes in the magnitude and direction of both the temperature standard deviation and skewness among all treatments suggest they may not be analytically reliable when applied in the field.

Linear trending analyses of stem surface temperatures largely supported the visual image evaluation process. Plants with the $3.8 \mathrm{~cm}$ void displayed a sharp deviation in the linear temperature trend near the position of the artificially induced void, and the magnitude of these localized deviations was significantly greater than those measured at the same position on the irrigated control (Plant 2). Although linear temperature deviations on both $D$. fragrans and $S$. grande measured $0.3^{\circ} \mathrm{C}$ below their respective averages, the linear temperature trend for $S$. grande visibly portrayed a comparably small and less distinct deviation around the $3.8 \mathrm{~cm}$ void when viewed in the coordinate plane. The deviation exhibited by $S$. grande remained noticeably different from the irrigated control, but the temperature gradient around the void position exhibited a shallower slope compared to the relatively steep gradient exhibited at the same position on $D$. fragrans. This disparity may be caused by the different stem geometry or bark thickness between these two species, with these features being substantially more pronounced in $S$. grande, or the different planting depths used for the two species.

The IR images were especially easy to interpret visually using the irrigated control temperature distribution as a reference case with which to compare other stems containing internal defects. In the field, the availability of a physically comparable reference specimen without internal defects would also be an important consideration when applying this technique. A control specimen would provide the comparative basis for evaluating temperature anomalies on the test subject, their absence from a control specimen, subjected to similar atmospheric conditions and solar radiation being a condition for positively identifying an internal defect. Overall, the qualitative image evaluation and linear trending analysis adequately identified the temperature anomaly associated with the largest internal void, while the temperatures extracted from rectangular tran- sects were, in some cases, contradictory to the conclusions facilitated by the other methods. In field applications, it may be adequate to rely exclusively on a visual image evaluation and linear trending analysis to identify similar temperature anomalies.

The basal gradient of progressively cooler temperatures on irrigated stems provided corroborative evidence of the effect of sap flow on surface temperature distributions (Wullschleger et al. 1998; Bauerle et al. 2002; Burcham et al. 2012). This natural gradient is caused by the actively conducting xylem fluids gradually warming from root to aboveground temperatures within the stem, and this has been reported in other species as being especially pronounced near the soil surface in relatively open or low-density forest areas (Köstner et al. 1998; Do and Rocheteau 2002). This temperature gradient will be common in relatively open urban landscapes, and its presence should not be erroneously attributed to internal defects.

Overall, these results are largely in agreement with earlier reports that stem temperature anomalies are limited to stems with internal defects occupying at least $76 \%$ cross-sectional area (Burcham et al. 2012). However, these findings extend current knowledge by demonstrating diurnal variation in the relationship between internal stem condition and surface temperature. Based on this variation, the observed temperature anomalies were likely caused by the reduced stem wall thickness made apparent only after the stems were passively heated by the sun. The change in stem geometry for those with the $3.8 \mathrm{~cm}$ void induced a measurable change in the stem's specific heat capacity, a material property predicting the change in temperature exhibited by a particular substance following a heat transfer (Joel 1996). Theoretically, specific heat capacity is described by an equation $\left(C=\frac{Q}{\Delta t}\right)$ where the ratio of heat transfer per unit mass $(\mathrm{J} / \mathrm{kg})$ and the resulting temperature change $(\mathrm{K})$ is described in units of $\mathrm{J} / \mathrm{kg} \mathrm{K}$ (Joel 1996). This property is mostly influenced by the temperature and moisture content of wood and is largely unaffected by density or species (Forest Products Laboratory 2010). Whereas the stem's specific heat capacity can be described by that of its wood in the absence of defects, a composite specific heat capacity must be considered for those in this experiment with a reduced stem wall thickness and air-filled voids. The two species exhibited measureable temperature changes in the evening when the defect exceeded $76 \%$ cross-sectional area, and the relatively low stem wall thickness in these specimens may have resulted in a measurable cooling effect by the air-filled void.

Although the wood anatomy of $D$. fragrans and $S$. grande are markedly different from one another, these two experiments allowed similar conclusions of this diagnostic technique's practical value. Still, the mechanically induced voids in this study can only be considered physically analogous to fungal-induced cavitations, and they likely did not accurately represent the complex physical, chemical, or biological conditions within a wood decay lesion (Adaskaveg et al. 1990; Deflorio et al. 2008). Similarly, the characteristic elements of a host defensive response, including cellular polyphenolic deposits, lignification, and suberization, were likely not manifest at the void periphery within the experimental timeframe (Pearce and Woodward 1986; Pearce 1996; Deflorio et al. 2009). The comparative physical complexity of wood decay lesions in mature, urban trees present a challenge to adapting the technique for practical risk assessments. Ultimately, it will be crucially important to further evaluate this technique using landscape trees with severe wood 
decay lesions. This would provide valuable information about the diagnostic technique's performance when evaluating material property changes caused by a dynamic host-fungus interaction.

\section{CONCLUSION}

These clarifications of the IR camera technique's resolution and precision under controlled experimental conditions are scientifically important and practically relevant. In this study, internal voids occupying more than $76 \%$ stem cross-sectional area produced obvious temperature anomalies in the evening. Although the ultimate conclusions about the diagnostic technique were similar for both plant species, the temperature change around the 3.8 $\mathrm{cm}$ void periphery was more pronounced in the $D$. fragrans linear temperature trend. The results suggest the technique can be used around nightfall in the tropics to detect relatively large internal defects, but the exact temperature differences between defective and healthy stems may not be consistent, particularly among different tree species, sizes, and shapes. In addition, it is unclear to what extent the conditions facilitating a positive identification of the largest void in this study can be found in typical landscape settings.

The findings reported from this experiment can broadly guide expectations about the technique's usefulness when applied to small trees with internal defects. The non-invasive measurements of the IR camera are highly appealing to arborists wishing to avoid any physical damage rendering a stem susceptible to wood decay infection, but the relatively low resolution of the device may impede greater professional acceptance and practical application. Commercially, there is a wide range of devices available that are able to detect and measure defects within tree stems, and many of these have comparatively higher resolution than reported here for the IR camera.

\section{LITERATURE CITED}

Adaskaveg, J.E., R.L. Gilbertson, and R.A. Blanchette. 1990. Comparative studies of delignification caused by Ganoderma species. Applied and Environmental Microbiology 56(6):1932-1943.

Bauerle, W.L., T.H. Whitlow, C.R. Pollock, and E.A. Frongillo. 2002. A laser-diode-based system for measuring sap flow by the heat pulse method. Agricultural and Forest Meteorology 110:275-284.

Beall, F.C., and W.W. Wilcox. 1987. Relationship of acoustic emission during radial compression to mass loss from decay. Forest Products Journal 37:38-42.

Bellett-Travers, M., and S. Morris. 2010. The relationship between surface temperature and radial wood thickness of twelve trees harvested in Nottinghamshire. Arboricultural Journal 33:15-26.

Brashaw, B.K., V. Bucur, F. Divos, R. Goncalves, J. Lu, R. Meder, R.F. Pellerin, S. Potter, R.J. Ross, X. Wang, et al. 2009. Nondestructive testing and evaluation of wood: A worldwide research update. Forest Products Journal 59(3):7-14.

Burcham, D.C., E.C. Leong, and Y.K. Fong. 2012. Passive infrared camera measurements demonstrate modest effect of mechanically induced internal voids on Dracaena fragrans stem temperature. Urban Forestry \& Urban Greening 11(2):169-178.

Burcham, D.C., E.C. Leong, Y.K. Fong, and P.Y. Tan. 2012. An evaluation of internal defects and their effect on trunk surface temperature in Casuarina equisetifolia L. (Casuarinaceae). Arboriculture \& Urban Forestry 28(6):277-286.
Burcham, D.C., S. Ghosh, E.C. Leong, and Y.K. Fong. 2011. Evaluation of an infrared camera technique for detecting mechanically induced internal voids in Syzygium grande. Arboriculture \& Urban Forestry 37:93-98.

Catena, A., and G. Catena. 2008. Overview of thermal imaging for tree assessment. Arboricultural Journal 30:259-270.

Catena, G., L. Palla, and M. Catalano. 1990. Thermal infrared detection of cavities in trees. European Journal of Forest Pathology 20:201-210.

Deflorio, G., C. Johnson, S. Fink, and F.W.M.R. Schwarze. 2008. Decay development in the sapwood of coniferous and deciduous trees inoculated with six wood decay fungi. Forest Ecology and Management 255:2373-2383.

Deflorio, G., E. Franz, S. Fink, and F.W.M.R. Schwarze. 2009. Host responses in the xylem of trees after inoculation with six wood-decay fungi differing in invasiveness. Botany 87:26-35.

Deflorio, G., S. Fink, and F.W.M.R. Schwarze. 2008. Detection of incipient decay in tree stems with sonic tomography after wounding and fungal inoculation. Wood Science and Technology 42:117-132.

Do, F., and A. Rocheteau. 2002. Influence of natural temperature gradients on measurements of xylem sap flow with thermal dissipation probes. 2. Advantages and calibration of a noncontinuous heating system. Tree Physiology 22:649-654.

Ellison, M. 2005. Quantified tree risk assessment used in the management of amenity trees. Journal of Arboriculture 31(2):57-65.

Evert, R.F. 2006. Esau's Plant Anatomy: Meristems, Cells, and Tissues of the Plant Body: Their Structure, Function, and Development, 3rd edition. John Wiley and Sons, Inc., Hoboken, New Jersey, U.S. 601 pp.

Forest Products Laboratory. 2010. Wood handbook: Wood as an engineering material. General Technical Report FPL-GTR-190. U.S. Department of Agriculture, Forest Service, Forest Products Laboratory, Madison, Wisconsin, U.S. 508 pp.

Greene, J.C., V.J. Caracelli, and W.F. Graham. 1989. Toward a conceptual framework for mixed-method evaluation designs. Educational Evaluation and Policy Analysis 11:255-274.

IBM, Corp., 2010. IBM ${ }^{\circledR}$ SPSS $^{\circledR}$ Statistics Version 19.0. International Business Machines Corp., NewYork, New York, U.S.

Joel, Rayner. 1996. Basic Engineering Thermodynamics, 5th edition. Addison Wesley Longman, Essex, England. 647 pp.

Johnstone, D., G. Moore, M. Tausz, and M. Nicolas. 2010. The measurement of wood decay in landscape trees. Arboriculture \& Urban Forestry 36(3):121-127.

Kane, B.C.P. and H.D.P. Ryan. 2004. The accuracy of formulas used to assess strength loss due to decay in trees. Journal of Arboriculture 30(6):347-356.

Kane, B.C.P., and H.D.P. Ryan. 2003. Examining formulas that assess strength loss due to decay in trees: Woundwood toughness improvement in red maple (Acer rubrum). Journal of Arboriculture 29(4):208-215.

Köstner, B., A. Granier, and J. Cermák. 1998. Sapflow measurements in forest stands: methods and uncertainties. Annals of Forest Science 55:13-27.

Larsson, B., B. Bengtsson, and M. Gustafsson. 2004. Nondestructive detection of decay in living trees. Tree Physiology 24(7):853-858.

Leong, E.C., D.C. Burcham, and Y.K. Fong. 2012. A purposeful classification of tree decay detection tools. Arboricultural Journal 34(2):91-115.

Matheny, N., and J. Clark. 1994. A Photographic Guide to the Evaluation of Trees in Urban Areas, 2nd edition. International Society of Arboriculture, Champaign, Illinois, U.S. 85 pp.

Matheny, N., and J. Clark. 2009. Tree risk assessment: What we know (and what we don't know). Arborist News 18(1):28-33. 
Nicolotti, G., and P. Miglietta. 1998. Using high-technology instruments to assess defects in trees. Journal of Arboriculture 24(6):297-302.

Norris, M. 2008. Urban tree risk assessment methods: What works, what does not, can we tell? Proceedings of the 84th International Society of Arboriculture Annual Conference and Trade Show. International Society of Arboriculture, Champaign, Illinois, U.S.

Pearce, R.B. 1996. Antimicrobial defences in the wood of living trees. New Phytologist 132:203-233.

Pearce, R.B., and S. Woodward. 1986. Compartmentalization and reaction zone barriers at the margin of decayed sapwood in Acer saccharinum L. Physiological and Molecular Plant Pathology 19:359-369.

Schwarze, F.W.M.R., J. Engels, and C. Mattheck. 2000. Fungal Strategies of Wood Decay in Trees. Berlin, Springer-Verlag. 185 pp.

Thermoteknix. 2001. TherMonitor ${ }^{\circledR}$ Reporter System User Manual. Thermoteknix Systems Limited, Cambridge, England.

Wang, X., and R.B. Allison. 2008. Decay detection in red oak trees using a combination of visual inspection, acoustic testing, and resistance microdrilling. Arboriculture \& Urban Forestry 34(1):1-4.

Wullschleger, S.D., F.C. Meinzer, and R.A. Vertessy. 1998. A review of whole-plant water use studies in trees. Tree Physiology 18:499-512.

Daniel C. Burcham (corresponding author)

Centre for Urban Greenery and Ecology

National Parks Board

Singapore 259569

daniel_burcham@nparks.gov.sg

Eng-Choon Leong

School of Civil and Environmental Engineering

Nanyang Technological University

Singapore 639798

Yok-King Fong

Centre for Urban Greenery and Ecology

National Parks Board

Singapore 259569

Puay-Yok Tan

School of Design and Environment

National University of Singapore

Singapore 117566

Résumé. La relation entre la température de la tige mesurée par une caméra à infrarouge et la condition interne de l'arbre a été proposée comme base pour le diagnostic de défauts potentiellement problématiques. Avant sa mise en application pratique, cette technique de diagnostic nécessite d'être clarifiée afin d'établir un guide quant aux attentes par rapport au degré de résolution et de précision. Dans cette étude, des cylindres vides de dimensions variées ont été créés dans des tiges de $5 \mathrm{~cm}$ de diamètre de Dracaena fragrans et de Syzygium grande en enlevant mécaniquement les tissus de spécimens produits en pépinière, et la température à la surface de ces végétaux a été mesurée sur une base journalière à deux reprises à 8:30 et 18:30 au moyen d'une caméra à infrarouge. Les images infrarouges ont été analysées par une approche faisant appel à des méthodes mixtes concurrentes d'évaluation qualitative de l'image et d'analyse quantitative de température en fonction des distributions de températures sur les tiges contenant des vides comparativement à celles sans vide. Il n'y avait pas de différence de températures sur la tige pour les deux espèces, et ce tel qu'observé sur les images infrarouges, parmi les végétaux expérimentaux à 8:30; mais une réduction anormale de température était exclusivement apparente à 18:30 près du vide de $3,8 \mathrm{~cm}$ qui occupait de ce fait $78 \%$ de la coupe transversale de la tige. Il y avait aussi une décroissance importante dans la température linéaire $\left(0,34-0,51^{\circ} \mathrm{C}\right)$ près de la marge du vide comparativement aux autres traitements; par contre cela était plus prononcé avec l'espèce monocotylédone que l'espèce dicotylédone. Les végétaux ayant subi le traitement ne présentaient pas de différence visible de température de leur tige par rapport à ceux du groupe témoin. Sous des conditions expérimentales, la technique a permis d'identifier des défauts internes relativement importants, mais la capacité réduite des tiges comportant des défauts de cette nature de contenir la chaleur est seulement apparente en soirée après avoir été réchauffée passivement par le soleil.

Zusammenfassung. Die Beziehung zwischen Stammtemperatur, gemessen mit einer Infrarotkamera, und den Konditionen im Stamminneren wurde als Basis herangezogen, um potentielle Schadmerkmale zu diagnostizieren. Vor der praktischen Anwendung braucht diese Diagnose-Technik eine Klarstellung, um die Erwartungen an die Genauigkeit und Lösungspotential in die richtige Richtung zu lenken. In dieser Studie wurden zylindrische Hohlräume verschiedener Größe in Dracaena fragrans und Syzygium grande Stämmen mit $5 \mathrm{~cm}$ Durchmesser kreiert, indem das Aussengewebe mechanisch in der Baumschule entfernt wurde und die Oberflächentemperatur zweimal am Tag um 08:30h und 18:30h mit einer Infrarotkamera gemessen wurde. Die gesammelten IREindrücke wurden mit verschiedenen Methoden inkl. einer qualitativen Bildbewertung und einer quantitativen Temperaturanalyse analysiert, wo die Temperaturverteilung bei Stämmen mit und ohne Hohlräume verglichen wurde. Bei beiden Arten gab es keine Differenzen bei der Stammtemperatur, wie auch beiden IR-Aufnahmen beobachtet, bei allen beteiligten Pflanzen in der Messung um 8:30h, aber es gab eine anormale Temperaturabsenkung, die ausschließlich um $18: 30 \mathrm{~h}$ bei dem 3,8 $\mathrm{cm}$ Loch auftrat, welches $76 \%$ der Stammscheibe ausmachte. Es gab auch einen größeren Abfall bei dem linearen Temperaturtrend $\left(0.34^{\circ} \mathrm{C}-\right.$ $0.51^{\circ} \mathrm{C}$ ) in der Nähe dieser defekten Zone, verglichen mit anderen Behandlungen, obwohl dieses eher für monokotyle als für eudikotyle Arten erwartet wurde. Die übrigen Behandlungen zeigten keine Temperaturveränderungen gegenüber den Kontrollmessungen. Unter experimentellen Bedingungen konnte diese Technik relativ große interne Defekte identifizieren, aber die reduzierte Wärme von Stämmen mit solchen Defekten wird nur sichtbar am Abend, wenn die Stämme durch die Sonne aufgewärmt sind.

Resumen. Se propuso la relación entre temperatura del tallo por una cámara infrarroja (IR) y la condición interna del árbol como base para el diagnóstico de defectos potencialmente peligrosos en el paisaje. Antes de la aplicación práctica, esta técnica de diagnóstico requiere clarificación para guiar las expectativas de su resolución y precisión. En este estudio, cavidades cilíndricas de tamaño variable fueron creadas en tallos de 5 $\mathrm{cm}$ de diámetro de Dracaena fragrans y Syzygium grande por remoción mecánica del tejido de especímenes en un vivero de las afueras, y la temperatura superficial de estas plantas fue medida dos veces diariamente a las $0830 \mathrm{~h}$ y $1830 \mathrm{~h}$ usando una cámara IR. Las imágenes IR colectadas fueron analizadas usando una aproximación de métodos mixtos actuales con evaluación cualitativa de las imágenes y análisis cuantitativo de la temperatura donde las distribuciones de temperatura de los tallos conteniendo cavidades internas fueron comparados con aquellos libres de defectos. Para ambas especies, no hubo diferencia en temperatura de los tallos, como se observó en las imágenes IR, entre cualquier planta del experimento a las $0830 \mathrm{~h}$, pero un reducción anómala de la temperatura fue exclusivamente aparente a las $1830 \mathrm{~h}$ cerca de la cavidad de 3.8 $\mathrm{cm}$, ocupando $76 \%$ de la sección transversal del tallo. También hubo una mayor disminución en la tendencia lineal de temperatura $\left(0.34^{\circ} \mathrm{C}-\right.$ $0.51^{\circ} \mathrm{C}$ ) cerca a esta cavidad comparado con otros tratamientos, a pesar que este fue más pronunciado en las especies monocotiledóneas que en dicotiledóneas. Los tratamientos remanentes no exhibieron temperaturas del tallo visiblemente diferentes de los controles. Bajo condiciones experimentales, la técnica identificó relativamente mayores defectos internos, pero capacidad reducida de calor de los tallos conteniendo tales defectos es solamente aparente en las tardes después de ser pasivamente calentados por el sol. 
Appendix. Statistical representation of stem surface temperature extracted from $10 \mathrm{~cm} \times 10 \mathrm{~cm}$ rectangular transects.

\begin{tabular}{|c|c|c|c|c|c|c|c|c|}
\hline \multicolumn{9}{|c|}{ Set 1: Dracaena fragrans ${ }^{z}$} \\
\hline \multirow{4}{*}{ Treatment } & \multicolumn{4}{|l|}{ Time } & \\
\hline & \multicolumn{2}{|l|}{ 0830h } & \multicolumn{2}{|l|}{$1830 \mathrm{~h}$} & \multicolumn{2}{|l|}{$\begin{array}{l}\text { Time } \\
\text { 0830h }\end{array}$} & \multicolumn{2}{|l|}{$1830 \mathrm{~h}$} \\
\hline & \multicolumn{4}{|c|}{ Surface-air temperature differential $\left({ }^{\circ} \mathrm{C}\right)$} & \multicolumn{4}{|c|}{ Standard deviation $\left({ }^{\circ} \mathrm{C}\right)$} \\
\hline & Mean \pm SD & $P$-value & Mean \pm SD & $P$-value & Mean \pm SD & $P$-value & Mean \pm SD & $P$-value \\
\hline 1 & $-0.35 \pm 0.07$ & 0.253 & $-1.64 \pm 0.29$ & 0.821 & $0.24 \pm 0.13$ & 0.514 & $0.23 \pm 0.03$ & 0.061 \\
\hline 2 & $-0.23 \pm 0.08$ & - & $-1.58 \pm 0.22$ & - & $0.20 \pm 0.07$ & - & $0.29 \pm 0.05$ & - \\
\hline 3 & $-0.19 \pm 0.06$ & 0.728 & $-1.41 \pm 0.22$ & 0.466 & $0.16 \pm 0.06$ & 0.615 & $0.24 \pm 0.04$ & 0.112 \\
\hline 4 & $-0.19 \pm 0.06$ & 0.752 & $-1.49 \pm 0.24$ & 0.693 & $0.16 \pm 0.05$ & 0.547 & $0.27 \pm 0.05$ & 0.509 \\
\hline 5 & $-0.11 \pm 0.10$ & 0.278 & $-1.33 \pm 0.30$ & 0.286 & $0.14 \pm 0.01$ & 0.370 & $0.22 \pm 0.03$ & $0.032^{y}$ \\
\hline 6 & $-0.13 \pm 0.09$ & 0.382 & $-1.50 \pm 0.26$ & 0.714 & $0.25 \pm 0.13$ & 0.453 & $0.23 \pm 0.04$ & $0.050^{\mathrm{y}}$ \\
\hline \multirow[t]{2}{*}{7} & $-0.13 \pm 0.27$ & 0.382 & $-1.62 \pm 0.41$ & 0.888 & $0.14 \pm 0.02$ & 0.424 & $0.17 \pm 0.02$ & $0.001^{\mathrm{y}}$ \\
\hline & \multicolumn{4}{|c|}{ Mean temperature $\left({ }^{\circ} \mathrm{C}\right)$} & \multicolumn{4}{|l|}{ Skewness (sk) } \\
\hline 1 & $25.60 \pm 1.72$ & 0.931 & $30.16 \pm 0.93$ & 0.942 & $1.79 \pm 1.23$ & 0.810 & $-0.86 \pm 0.02$ & $0.001^{y}$ \\
\hline 2 & $25.73 \pm 1.74$ & - & $30.21 \pm 0.91$ & - & $1.58 \pm 1.38$ & - & $-0.23 \pm 0.21$ & - \\
\hline 3 & $25.76 \pm 1.72$ & 0.980 & $30.39 \pm 0.91$ & 0.814 & $0.70 \pm 1.15$ & 0.322 & $-0.26 \pm 0.08$ & 0.854 \\
\hline 4 & $25.76 \pm 1.74$ & 0.981 & $30.31 \pm 0.88$ & 0.899 & $0.58 \pm 0.94$ & 0.260 & $-0.14 \pm 0.14$ & 0.507 \\
\hline 5 & $25.84 \pm 1.76$ & 0.935 & $30.47 \pm 0.87$ & 0.728 & $0.44 \pm 0.36$ & 0.203 & $-0.25 \pm 0.14$ & 0.890 \\
\hline 6 & $25.82 \pm 1.69$ & 0.948 & $30.30 \pm 0.89$ & 0.906 & $2.02 \pm 1.35$ & 0.618 & $-0.26 \pm 0.34$ & 0.836 \\
\hline 7 & $25.82 \pm 1.70$ & 0.948 & $30.18 \pm 0.82$ & 0.964 & $0.21 \pm 0.38$ & 0.131 & $0.06 \pm 0.10$ & 0.058 \\
\hline \multicolumn{9}{|c|}{ Set 2: Syzygium grande } \\
\hline Treatment & \multicolumn{4}{|c|}{ Surface-air temperature differential $\left({ }^{\circ} \mathrm{C}\right)$} & \multicolumn{4}{|c|}{ Standard deviation $\left({ }^{\circ} \mathrm{C}\right)$} \\
\hline$\overline{1}$ & $-0.61 \pm 0.22$ & 0.147 & $-0.92 \pm 0.42$ & 0.258 & $0.17 \pm 0.02$ & 0.327 & $0.26 \pm 0.07$ & 0.311 \\
\hline 2 & $-0.78 \pm 0.07$ & - & $-0.32 \pm 0.51$ & - & $0.22 \pm 0.06$ & - & $0.22 \pm 0.01$ & - \\
\hline 3 & $-0.61 \pm 0.15$ & 0.147 & $-0.25 \pm 0.66$ & 0.893 & $0.21 \pm 0.04$ & 0.818 & $0.16 \pm 0.03$ & 0.078 \\
\hline 4 & $-0.76 \pm 0.09$ & 0.881 & $-0.51 \pm 0.89$ & 0.720 & $0.19 \pm 0.05$ & 0.594 & $0.24 \pm 0.01$ & 0.608 \\
\hline 5 & $-0.65 \pm 0.10$ & 0.252 & $-0.05 \pm 0.34$ & 0.605 & $0.19 \pm 0.07$ & 0.594 & $0.29 \pm 0.06$ & 0.053 \\
\hline 6 & $-0.61 \pm 0.11$ & 0.133 & $-0.22 \pm 0.68$ & 0.843 & $0.20 \pm 0.07$ & 0.702 & $0.27 \pm 0.03$ & 0.193 \\
\hline 7 & $-0.64 \pm 0.06$ & 0.219 & $-0.19 \pm 0.55$ & 0.803 & $0.20 \pm 0.04$ & 0.760 & $0.22 \pm 0.02$ & 1.000 \\
\hline \multirow[t]{2}{*}{8} & $-0.58 \pm 0.19$ & 0.082 & $-0.81 \pm 0.78$ & 0.353 & $0.19 \pm 0.06$ & 0.494 & $0.30 \pm 0.04$ & $0.023^{y}$ \\
\hline & \multicolumn{4}{|c|}{ Mean temperature $\left({ }^{\circ} \mathrm{C}\right)$} & \multicolumn{4}{|l|}{ Skewness (sk) } \\
\hline 1 & $25.47 \pm 1.76$ & 0.907 & $28.85 \pm 0.65$ & 0.260 & $-0.12 \pm 0.43$ & 0.543 & $-0.75 \pm 0.20$ & $0.046^{y}$ \\
\hline 2 & $25.30 \pm 1.73$ & - & $29.45 \pm 0.71$ & - & $0.20 \pm 0.87$ & - & $-1.32 \pm 0.38$ & - \\
\hline 3 & $25.47 \pm 1.67$ & 0.907 & $29.52 \pm 0.55$ & 0.893 & $0.66 \pm 1.24$ & 0.374 & $-0.28 \pm 0.10$ & $0.001^{\mathrm{y}}$ \\
\hline 4 & $25.32 \pm 1.72$ & 0.991 & $29.26 \pm 0.13$ & 0.721 & $-0.29 \pm 0.21$ & 0.351 & $-0.93 \pm 0.37$ & 0.156 \\
\hline 5 & $25.43 \pm 1.69$ & 0.927 & $29.72 \pm 0.68$ & 0.607 & $-0.25 \pm 0.22$ & 0.397 & $-1.14 \pm 0.64$ & 0.509 \\
\hline 6 & $25.48 \pm 1.76$ & 0.903 & $29.55 \pm 0.82$ & 0.843 & $-0.39 \pm 0.47$ & 0.269 & $-0.39 \pm 0.03$ & $0.003^{y}$ \\
\hline 7 & $25.44 \pm 1.78$ & 0.922 & $29.58 \pm 0.82$ & 0.804 & $-0.27 \pm 0.28$ & 0.374 & $-0.38 \pm 0.23$ & $0.003^{y}$ \\
\hline 8 & $25.51 \pm 1.61$ & 0.886 & $28.96 \pm 0.35$ & 0.355 & $0.12 \pm 0.50$ & 0.887 & $0.05 \pm 0.24$ & $0.000^{y}$ \\
\hline
\end{tabular}

${ }^{\mathrm{z}}$ Number of repeated measures $(\mathrm{n}=4)$

y Represents a significant difference $(P<0.05)$ from Treatment 2 , the irrigated control. 